\title{
PEMBUATAN VERMIKOMPOS MENGGUNAKAN LIMBAH FLESHING DI INDUSTRI PENYAMAKAN KULIT
}

\section{VERMICOMPOSTING OF FLESHING WASTE AT THE TANNERY INDUSTRY}

\author{
Prayitno \\ Balai Besar Kulit, Karet, dan Plastik, Yogyakarta \\ E-mail: prayitno_bbkkp@yahoo.com
}

Diterima: 18 Oktober 2013 Direvisi: 10 Desember 2013 Disetujui: 20 Desember 2013

\begin{abstract}
A research on utilization of fleshing waste at the tannery industry by vermicomposting have been conducted. The growth media consist of dung, fleshing waste, and stubbles. Ratio of dung and fleshing waste were varied at 100:0; 90:10; 80:20; 70:30; 60:40; and 50:50 respectively. All the media were fermented for three weeks and then proceeded by incubation process of earthworm for another six weeks. The changes of the volume per weight of media, the earthworm weight, $C$, $N$, and $C / N$ ratio were observed and measured every week. The result showed that media volume per weight value were decreased in direct proportional to weight of the fleshing waste added in the media, those were $1.66 ; 1.64 ; 1.53 ; 1.50 ; 1.39 ;$ and $1.31 \mathrm{~cm}^{3} / \mathrm{g}$, respectively. $C / N$ ratio were below 15 for all combination of media ratio after two weeks incubation. The optimum result was achieved for compost with dung and fleshing waste ratio of 60:40.
\end{abstract}

Keywords: Earthworm, fleshing waste, C/N ratio, vermicomposting.

\section{ABSTRAK}

Telah dilakukan penelitian pemanfaatan limbah sisa fleshing pada proses penyamakan kulit untuk pembuatan kompos menggunakan cacing tanah. Penelitian ini dilakukan dengan membuat media pertumbuhan cacing tanah yang terdiri atas campuran kotoran sapi, sisa fleshing, dan potongan jerami. Perbandingan antara kotoran sapi dengan limbah fleshing berturut-turut 100:0; 90:10; 80:20; 70:30; 60:40; dan 50:50. Fermentasi campuran bahan kompos dilakukan selama 3 minggu dan dilanjutkan pemeraman cacing selama 6 minggu. Setiap minggu dilakukan pengamatan terhadap parameter keberhasilan pembuatan media habitat cacing tanah yang meliputi nilai keambanan media, berat cacing, unsur $\mathrm{C}$, unsur $\mathrm{N}$ dan rasio $\mathrm{C} / \mathrm{N}$. Hasil percobaan menunjukan keambanan media turun seiring dengan jumlah limbah fleshing yang ditambahkan, berturut-turut sebesar 1,$66 ; 1,64 ; 1,53$; 1,$50 ; 1,39 ;$ dan $1,31 \mathrm{~cm}^{3} / \mathrm{g}$, sedangkan rasio $\mathrm{C} / \mathrm{N}$ hingga dibawah 15 untuk semua perlakuan dicapai setelah inkubasi 2 (dua) minggu. Rasio $\mathrm{C} / \mathrm{N}$ optimum diperoleh pada perlakuan dengan perbandingan kotoran sapi dengan fleshing 60:40.

Kata kunci: cacing tanah, limbah fleshing, rasio $\mathrm{C} / \mathrm{N}$, vermikompos.

\section{PENDAHULUAN}

Industri penyamakan kulit adalah industri yang mengolah kulit mentah (hide atau skin) menjadi kulit tersamak (leather). Penyamakan dimaksudkan untuk mengubah sifat-sifat kulit mentah yang mudah rusak dan busuk menjadi kulit tersamak yang tahan terhadap aktivitas mikrobia dan pembusukan. Secara garis besar, proses penyamakan kulit mentah menjadi kulit tersamak dilakukan dalam tiga tahap utama meliputi pengolahan kulit basah, penyamakan kulit, dan finishing. Dari tiga proses tersebut, pengolahan basah banyak menghasilkan limbah cair karena dalam proses memerlukan banyak 
air. Salah satu tahap adalah pembuangan sisa daging (fleshing). Proses ini dimaksudkan untuk melepaskan sisa daging dan lemak yang masih melekat pada kulit. Jumlah limbah padat yang dihasilkan dalam tahap fleshing cukup besar, dari 1 ton kulit mentah dapat dihasilkan antara 70-230 kg limbah buang daging (Kanagaraj et al., 2006). Limbah daging sangat potensial mencemari lingkungan karena mudah busuk dan hancur. Kandungan unsur $\mathrm{N}$ protein tersisa dalam limbahfleshing dapat dimanfaatkan untuk berbagai keperluan. Salah satunya adalah untuk sumber nitrogen pada pembuatan pupuk organik sistem pembuatan kompos, yaitu memecah ikatan panjang dari bahan organik menjadi ikatan pendek dengan bantuan mikrobia agar dapat diserap oleh akar tumbuh-tumbuhan.

Akhir-akhir ini telah banyak dikembangkan pembuatan kompos dengan metode vermikomposting. Vermikomposting adalah proses pembuatan kompos dari hasil perombakan bahan-bahan organik yang dilakukan oleh cacing tanah yang hasilnya disebut vermikompos. Vemikompos merupakan campuran kotoran cacing tanah (casting) dengan sisa media atau pakan untuk budidaya cacing tanah. Oleh karena itu vermikompos merupakan pupuk organik yang ramah lingkungan dan memiliki keunggulan tersendiri dibandingkan dengan kompos lain yang dikenal selama ini (Karmakar et al., 2012). Berbagai spesies cacing tanah yang telah dicoba pada penelitian tentang vermikomposting antara lain Eisenia fetida (Garg and Gupta, 2011; Molina et al., 2013), Perionyx ceylanensis (Prakash and Karmegam, 2010; Paul et al., 2011), Perionyx excavatus (Deka et al., 2011; Pattnaik and Reddy, 2012), dan Eudrilus eugeniae (Pramanik and Chung, 2011; Raphael and Velmourougane, 2011), sedangkan limbah yang diolah antara lain limbah pasar atau industri makanan (Gurav and Pathade, 2011; Majlessi et al., 2012), peternakan (Ngo et al., 2011; Gómez-Brandón et al., 2013), obat herbal (Singh and Suthar, 2012), dan minyak aromatik (Deka et al., 2011).

Kandungan bahan organik dan nitrogen yang tinggi pada limbah fleshing berarti bahan ini dapat digunakan untuk pengkayaan media pertumbuhan cacing dan untuk mendegradasi bahan-bahan baik hidrokarbon maupun protein.
Dengan demikian diharapkan pembuatan kompos limbah fleshing akan dapat digunakan oleh hewan invertebrata jenis cacing tanah sebagai sumber makanannya. Sedangkan kotoran cacing yang dihasilkan dimanfaatkan untuk penyuburan tanah, pembunuh bakteri patogen, dan penahan air tanah (Sinha et al., 2009). Diharapkan pembuatan vermikompos dapat berperan untuk penyelesaian permasalahan yang terkait dengan penanganan limbah fleshing pada industri penyamakan kulit. Limbah fleshing merupakan sisa daging yang kaya unsur nitrogen, sehingga untuk pembuatan kompos diperlukan tambahan sumber carbon yang dapat diperoleh dari kotoran sapi maupun sisa tumbuhtumbuhan yang dalam penelitian ini digunakan potongan jerami. Tujuan penelitian ini adalah untuk mendapatkan perbandingan yang tepat antara sumber karbon (kotoran sapi) dan sumber nitrogen (limbah fleshing) untuk pembuatan vermikompos dengan bantuan cacing tanah.

\section{BAHAN DAN METODE \\ Bahan Penelitian}

Bahan penelitian terdiri atas cacing tanah Eisenia foetida sp. dengan bobot tubuh berkisar 7-8 g/30 ekor. Cacing tanah diperoleh dari hasil pemeliharaan petani peternak cacing di daerah Kasongan, Bantul, Yogyakarta. Kotoran sapi diperoleh dari kandang sapi milik penduduk di daerah Sitimulyo, Kabupaten Bantul, Yogyakarta. Limbah fleshing diperoleh dari Laboratorium Proses Kulit, Balai Besar Kulit, Karet, dan Plastik di Sitimulyo, Bantul. Bahan lainnya adalah jerami, stater EM4, gula pasir, dan kapur.

\section{Peralatan Penelitian}

Timbangan kapasitas $5 \mathrm{~kg}$, timbangan elektrik, termometer, penyemprot air, dan ruangan untuk inkubasi.

\section{Metode Penelitian \\ Penyiapan media kompos}

Kotoran sapi diambil pada pagi hari selama tujuh hari untuk mengurangi kadar air dan amonia. Limbah fleshing dicuci dan dicacah, kemudian di jemur pada sinar matahari untuk menggurangi kadar air dan mencegah pembusukan. Kotoran sapi dicampur dengan 
Tabel 1. Format perbandingan kotoran sapi, limbah fleshing dan potongan jerami untuk pembuatan kompos

\begin{tabular}{lcccccc}
\hline \multirow{2}{*}{ Jenis bahan } & \multicolumn{7}{c}{ Perlakuan } \\
\cline { 2 - 7 } & $\mathrm{A}$ & $\mathrm{B}$ & $\mathrm{C}$ & $\mathrm{D}$ & $\mathrm{E}$ & $\mathrm{F}$ \\
\hline Kotoran sapi, \% & 100 & 90 & 80 & 70 & 60 & 50 \\
Jerami, \% & 2 & 2 & 2 & 2 & 2 & 2 \\
Limbah fleshing, \% & 0 & 10 & 20 & 30 & 40 & 50 \\
\hline
\end{tabular}

Keterangan: (A) Kompos dengan 100\% kotoran hewan, (B) Kompos dengan 90\% kotoran hewan $+10 \%$ limbah fleshing, (C) Kompos dengan 80\% kotoran hewan $+20 \%$ limbah fleshing, (D) Kompos dengan $70 \%$ kotoran hewan $+30 \%$ limbah fleshing, (E) Kompos dengan $60 \%$ kotoran hewan $+40 \%$ limbah fleshing, (F) Kompos dengan 50\% kotoran hewan $+50 \%$ limbah fleshing

limbah fleshing dan potongan jerami sesuai taraf perlakuan. Perbandingan antara kotoran sapi, limbah fleshing dan jerami seperti disajikan pada Tabel 1.

\section{Formulasi media kompos}

Penyiapan media cacing tanah digunakan starter EM4 dengan komposisi seperti disajikan pada Tabel 2.

\section{Cara kerja setiap penyiapan formula media}

Pupuk kandang, jerami dan limbah fleshing dicampur sampai merata, dibuat media starter dengan cara larutan starter, gula pasir dan air sumur dicampur sambil diaduk sampai merata dan didiamkan semalam (6-10 jam). Selanjutnya, media starter dicampur dengan media kompos dalam ember plastik dan ditutup dengan karung goni, dibiarkan agar fermentasi berlangsung. Setiap 6 jam suhu diamati dan dijaga tetap antara $40-50^{\circ} \mathrm{C}$, apabila suhu naik lebih dari $50^{\circ} \mathrm{C}$ dilakukan pengadukan. Suhu di cek dan diatur sampai mencapai suhu kamar, baru dilakukan budidaya cacing untuk setiap media yang disiapkan. Nilai keambanan media (perbandingan volume dan bobot media) diamati pada awal budidaya, sedangkan unsur $\mathrm{C}$, unsur $\mathrm{N}$ dan rasio $\mathrm{C} / \mathrm{N}$ diamati setiap dua minggu..

Tabel 2. Formulasi media kompos untuk budidaya cacing tanah

\begin{tabular}{lc}
\hline \multicolumn{1}{c}{ Jenis bahan } & Bagian \\
\hline Media kompos (kotoran sapi, & \\
limbah fleshing dan jerami) & 1000 \\
Starter/inokulum EM4 & 1 \\
Gula pasir & 1 \\
Air sumur & 100 \\
\hline
\end{tabular}

Kelembaban, unsur $\mathrm{C}$, dan unsur $\mathrm{N}$ diamati hingga nilai rasio $\mathrm{C} / \mathrm{N}<15$. Cacing tanah yang digunakan untuk setiap perlakuan sebanyak 30 ekor, sehinga untuk 6 perlakuan dan 3 kali ulangan diperlukan cacing sebanyak 30x18 ekor. Cacing tanah yang digunakan berasal dari hasil budidaya dan pemeliharaan. Media cacing tanah hasil fermentasi diangin-anginkan selama \pm 3 hari agar gas dan kadar air berkurang, kemudian ditambah 0,3\% kapur $\left(\mathrm{CaCO}_{3}\right)$. Beberapa ekor cacing tanah ditempatkan pada permukaan media dan dibiarkan selama $2 \times 24$ jam. Media pertumbuhan sudah dapat digunakan sebagai habitat hidup cacing tanah apabila cacing tanah tidak keluar dari media atau mati. Cacing yang dipelihara dari setiap wadah adalah 30 ekor dengan bobot tubuh antara 9-11 g/30 ekor. Wadah ditempatkan pada rak-rak kayu dan ditutup dengan kertas koran agar suasananya gelap. Suhu dan kelembaban media dikur secara terus menerus agar dapat dipertahankan konstan. Penyemprotan air dilakukan dengan handsprayer setiap 2 hari sekali agar kelembaban media cacing terjaga tetap. Media tumbuh cacing diaduk setiap 1 minggu sekali agar aerasi berjalan baik. Pemeliharaan selama 3 x 2 minggu (6 minggu) dan cacing tanah tidak diberi pakan tambahan agar dapat diketahui berapa lama media dapat memberikan nutrisi untuk pertumbuhan cacing tanah.

\section{Rancangan percobaan}

Rancangan percobaan yang digunakan adalah Rancangan Acak Lengkap (RAL) pola searah, terdiri atas 6 taraf perlakuan campuran kotoran sapi dengan limbah fleshing. Tiap taraf perlakuan didapat 3 kali ulangan sehingga 
diperoleh 18 unit percobaan dan tiap satuan pengamatan media terdiri atas 30 ekor cacing tanah. Pengamatan dilakukan dalam setiap 2 minggu selama 3(tiga) kali pengamatan. Unsur $\mathrm{C}$, unsur $\mathrm{N}$ dan ratio $\mathrm{C} / \mathrm{N}$ diamati sampai kompos telah masak $(\mathrm{C} / \mathrm{N}<15)$.

\section{Parameter yang diamati}

Keambanan media yaitu perbandingan volume dan bobot media sesuai persamaan (1):

$$
\text { Nilai keambanan }=\frac{\text { Volume }}{\text { Berat }}\left(\mathrm{cm}^{3} / \mathrm{g}\right)
$$

Keambanan diukur pada awal pencampuran kompos agar perubahan volume dan bobot dari campuran media pertumbuhan dapat diketahui secara pasti.

\section{Analisis unsur $\mathrm{C}, \mathrm{N}$, dan $\operatorname{rasio} \mathrm{C} / \mathrm{N}$}

Analisis unsur $\mathrm{C}, \mathrm{N}$ dan rasio $\mathrm{C} / \mathrm{N}$ dilakukan di Laboratorium Tanah, Fakultas Pertanian UGM. Setiap 2 minggu sekali dilakukan analisis rasio $\mathrm{C} / \mathrm{N}$ sampai batas waktu ratio $\mathrm{C} / \mathrm{N}$ mencapai $\leq 15$. Pada kondisi demikian kompos dianggap telah masak atau layak pakai. Analisa unsur $\mathrm{C}$ dilakukan dengan metode pengabuan menggunakan muffle furnace, sedangkan unsur $\mathrm{N}$ dengan metoda Kjeldahl.

\section{Analisis data}

Data dievaluasi secara statistik dengan sidik ragam atau analisis of variance (ANOVA) pada taraf kepercayaan 0,05 . Perlakuan yang berpengaruh nyata terhadap parameter yang diamati diuji lanjut dengan uji Duncan Multiple Ring Test (DMRT) untuk mengetahui perbedaan pengaruh diantara perlakuan.

\section{HASIL DAN PEMBAHASAN Nilai Keambanan}

Nilai keambanan menggambarkan kepadatan kompos sebagai media untuk cacing. Media yang terlalu padat dapat menyebabkan terganggunya pertumbuhan dari cacing. Media yang terlalu padat menyebabkan cacing tanah sulit bernafas dan kemungkinan keracunan gas COyangterbentuk. Hasilpercobaan penambahan limbah fleshing pada kompos memberikan data seperti disajikan pada Gambar 1.

Gambar 1 menunjukan bahwa penambahan fleshing menurunkan nilai keambanan media pertumbuhan cacing tanah. Hal ini berarti menambah kerapatan media, sehingga

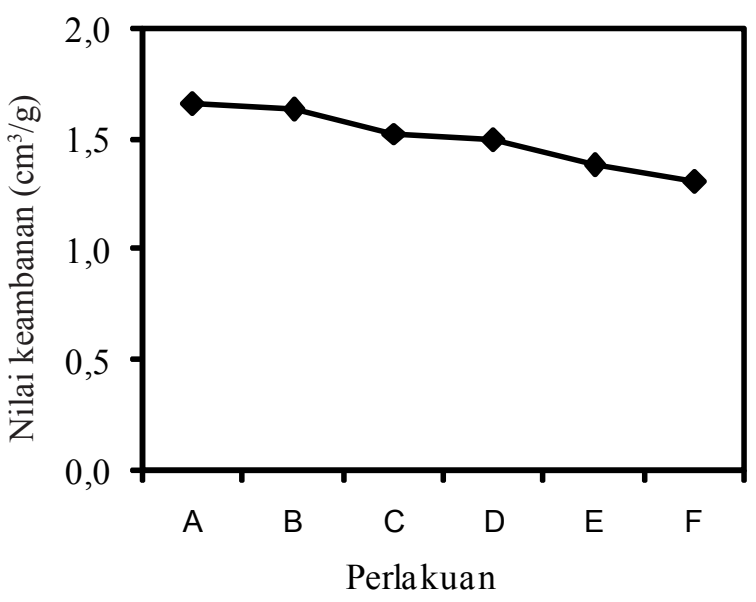

Gambar 1. Grafik nilai keambanan media

menghambat difusi udara ke media. Dengan demikian, pertumbuhan cacing tanah terganggu. Penetrasi udara dan pelepasan gas yang terbentuk dalam media pertumbuhan perlu ditingkatkan melalui pembalikan media setiap dua hari. Analisis statistik dengan metode faktorial sederhana dengan taraf kepercayaan 95\% menunjukan bahwa penambahan fleshing ternyata berpengaruh nyata menurunkan keambanan dari media pertumbuhan cacing $\left(\mathrm{F}_{\mathrm{ht}=7.0287}>\mathrm{F}_{\text {tabel=3.1059 }}\right)$ sehingga media semakin padat. Nilai keambanan pada perlakuan A, B, C, D, E, dan F berturut-turut 1,$66 ; 1,64 ; 1,53$; 1,$50 ; 1,39 ;$ dan $1,31 \mathrm{~cm}^{3} / \mathrm{g}$. Melalui analisis dengan LSD 5\% diketahui bahwa penurunan nyata keambanan terjadi setelah penambahan limbah fleshing dengan perbandingan antara kotoran hewan dan limbah fleshing berturut-turut 70:30; 60:40; dan 50:50. Penurunan keambanan berlangsung landai pada setiap perbandingan kotoran hewan dan limbah fleshing dengan nilai setara $20 \%$.

\section{Nutrisi Media Budidaya Cacing Tanah}

Media pertumbuhan cacing tanah membutuhkan nutrisi atau komponen tertentu seperti protein, karbohidrat, dan mineral. Cacing tanah melakukan degradasi bahan-bahan secara sempurna menjadi senyawa sederhana yang lebih mudah diserap makluk hidup. Kompos harus diperam (fermentasi) terlebih dahulu untuk mempermudah kompos dihancurkan oleh cacing tanah. Fermentasi dilakukan selama 3 minggu, kemudian dilakukan pengukuran unsur $\mathrm{C}, \mathrm{N}$, dan rasio $\mathrm{C} / \mathrm{N} 1$ kali untuk setiap 
2 minggu hingga tercapai ratio $\mathrm{C} / \mathrm{N} \leq 15$ yang menandakan kompos sudah masak.

\section{Kandungan Unsur Karbon (C)}

Hasil pengukuran unsur karbon seperti disajikan pada Gambar 2 yang menunjukan bahwa kadar unsur karbon naik sejalan dengan penambahan limbah fleshing. Seratus bagian kotoran hewan setelah difermentasi besarnya kandungan unsur karbon yaitu 25,94\%. Menurut Achmad et al. (2010), kandungan unsur $\mathrm{C}$ pada kotoran sapi 9,7\%. Penambahan potongan jerami dan limbah fleshing meningkatkan kadar unsur $\mathrm{C}$ pada media. Dengan kenaikan jumlah limbah fleshing dan perbandingan kotoran hewan dan limbah fleshing berturut-turut 90:10, 80:20, 70:30, 60:40, dan 50:50 menaikan kadar unsur karbon menjadi berturut-turut 29,66; 30,36; 33,$10 ; 36,30$; dan $36,13 \%$. Hal ini diduga karena limbah fleshing banyak mengandung lemak dengan ikatan hidrokarbon panjang yang akan dipecah menjadi unsur karbon saat fermentasi berlangsung.

Fermentasi yang disertai inkubasi cacing menurunkan kadar unsur karbon di setiap perlakuan. Hal ini diduga karena unsur karbon diserap oleh cacing sebagai sumber tenaga. Kadar unsur karbon selama proses inkubasi turun, dan untuk kompos dengan $100 \%$ kotoran hewan penurunan terjadi pada minggu ke-2 dan ke-4 dari $25,94 \%$ menjadi berturut-turut $23,97 \%$ dan $15,34 \%$. Kompos dengan perbandingan 90 bagian kotoran hewan dan 10 bagian limbah fleshing terjadi penurunan kadar unsur karbon berturut-turut dari $29,66 \%$ menjadi $26,48 \%$ dan $25,74 \%$. Sedangkan kompos dengan perbandingan 80 bagian kotoran hewan dan 20 bagian limbah fleshing terjadi penurunan kadar unsur karbon dari $30,36 \%$ menjadi berturut-turut $23,37 \%$ dan $26,46 \%$.

Kompos dengan perbandingan 70 bagian kotoran hewan dengan 30 bagian limbah fleshing menyebabkan kadar unsur karbon turun dari 33,10\% menjadi berturutturut $30,27 \%$ dan $27,82 \%$. Kompos dengan perbandingan 60 bagian kotoran hewan dengan 40 bagian limbah fleshing menyebabkan kadar unsur karbon turun dari 36,30\% menjadi

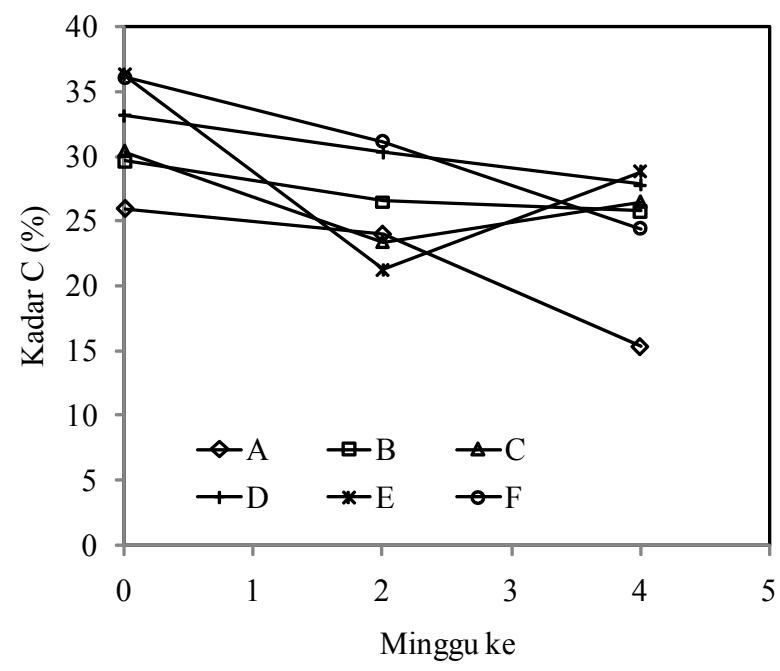

Gambar 2. Grafik hasil pengujian kadar unsur karbon

berturut-turut $21,24 \%$ dan $28,80 \%$. Untuk kompos dengan perbandingan 50 bagian kotoran hewan dengan 50 bagian limbah fleshing akan terjadi penurunan kadar unsur karbon berturut-turut $36,13 \%$ menjadi $31,14 \%$ dan 24,36\%. Penurunan kadar unsur karbon pada media pertumbuhan seiring dengan meningkatnya waktu inkubasi diartikan adanya degradasi dari bahan-bahan organik rantai panjang menjadi unsur karbon. Sebagian unsur karbon digunakan untuk pertumbuhan mikroba dan juga untuk pertumbuhan cacing tanah. Unsur karbon dalam kompos dapat diserap tumbuh-tumbuhan. Kandungan unsur karbon tertinggi yaitu $28,80 \%$ diperoleh pada media dengan perbandingan kotoran hewan dengan limbah fleshing 60:40 dan terendah yaitu $24,36 \%$ diperoleh pada media dengan perbandingan kotoran hewan dengan fleshing 50:50 sesuai dengan hasil penelitian Gurav and Pathade (2011) pada penelitian pembuatan vermikomposting dengan media pertumbuhan cacing tanah menggunakan capuran kotoran hewan dan sisa tumbuh-tumbuhan (daun, bunga, buah) yang dikumpulkan dari kuil Nirmalaya menghasilkan kompos dengan kandungan unsur karbon $28 \%$.

\section{Kadar Unsur Nitrogen (N)}

Pengukuran kadar unsur $\mathrm{N}$ disajikan pada Gambar 3. Gambar 3 menunjukan bahwa saat uji awal (minggu 0) kadar unsusr $\mathrm{N}$ untuk 


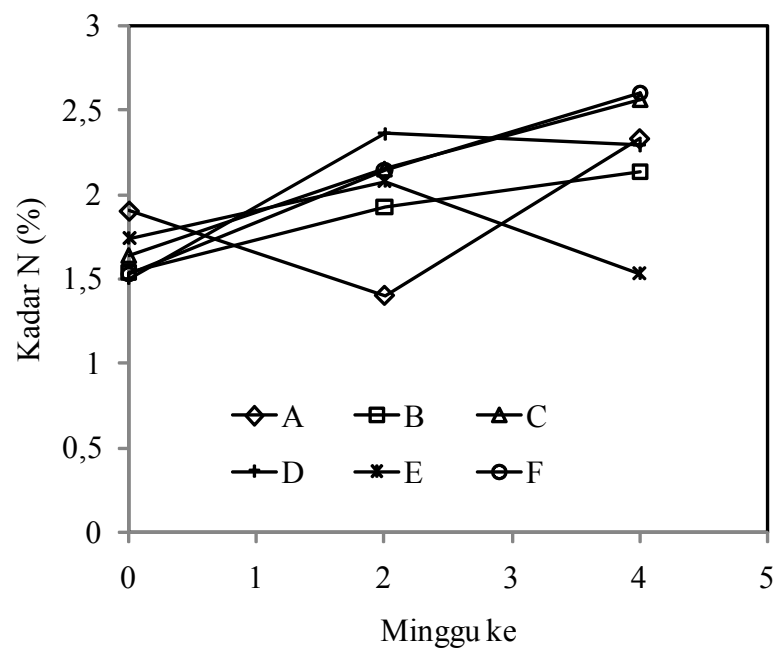

Gambar 3. Grafik hasil pengujian kadar unsur N

setiap perlakuan hampir tetap, yakni berturutturut $1,90 \% ; 1,54 \% ; 1,64 \% ; 1,50 \% ; 1,74 \%$; dan $1,53 \%$ untuk kompos dengan perbandingan antara kotoran sapi dan limbah fleshing berturut-turut 100:0, 90:10, 80:20, 70:30, 60:40 dan 50:50. Hal ini mengindikasikan bahwa limbah fleshing lebih tinggi kandungan lemaknya daripada daging atau kemungkinan dikarenakan oleh fermentasi saja tidak cukup untuk mendegradasi kandungan protein. Setelah cacing tanah diinkubasikan selama 2 dan 4 minggu, untuk setiap media dengan perlakuan perbandingan antara kotoran hewan dan limbah fleshing ada kenaikan kadar unsur N. Kenaikan kadar unsur $\mathrm{N}$ pada inkubasi 0, 2, dan 4 minggu berturut-turut untuk media dengan perbandingan antara kotoran hewan dan limbah fleshing 100:0 unsur N naik berturut-turut 1,90; 1,40; dan 2,33\%; media dengan perbandingan 90:10 unsur $\mathrm{N}$ naik berturut-turut 1,54; 1,93 dan $2,14 \%$; media dengan perbandingan 80:20 unsur $\mathrm{N}$ naik berturut-turut 1,$64 ; 2,15$; dan 2,56\%; media dengan perbandingan 70:30 unsur $\mathrm{N}$ naik berturut-turut 1,$59 ; 2,36 ; 2,29 \%$; media dengan perbandingan 60:40 unsur $\mathrm{N}$ naik berturut-turut; 1,$74 ; 2,08$; dan $2,57 \%$ sedangkan media dengan perbandingan 50:50 unsur $\mathrm{N}$ naik berturutturut 1,$53 ; 2,14$; dan 2,60\%. Kenaikan unsur N ini sejalan dengan waktu degradasi dari protein yang terkandung dalam kotoran sapi dan dalam limbah fleshing. Menurut Achmad et al. (2010) kadar unsur $\mathrm{N}$ pada kotoran sapi sebesar $0,65 \%$, penambahan limbah fleshing meningkatkan

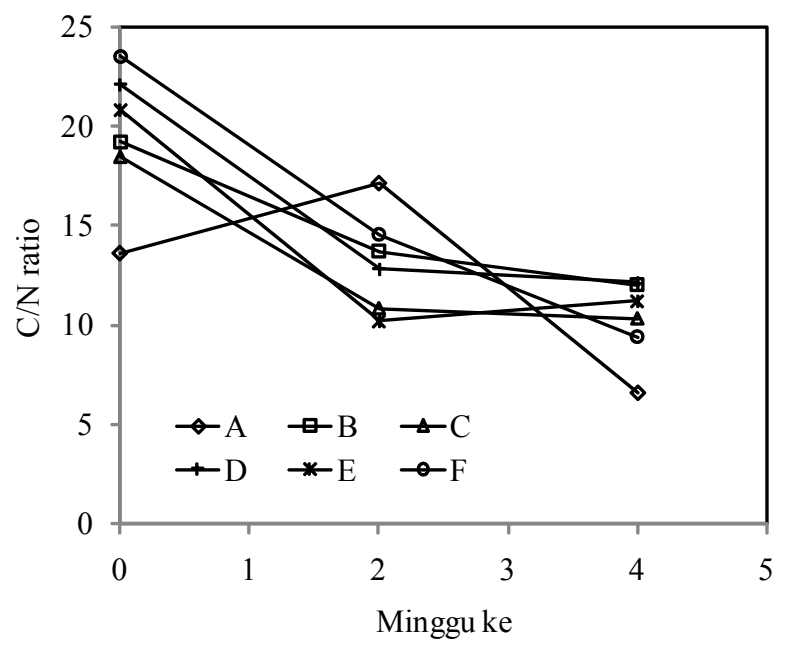

Gambar 4. Rasio $\mathrm{C} / \mathrm{N}$ dari kompos dengan berbagai perbandingan kotoran hewan dan limbah fleshing

kadar $\mathrm{N}$ pada media pertumbuhan cacing tanah. Kadar unsur $\mathrm{N}$ tertinggi diperoleh pada perlakuan dengan 50 bagian kotoran hewan dan 50 bagian limbah fleshing yaitu sebesar 2,60\%. Kadar unsur $\mathrm{N}$ pada hasil akhir kompos semua memenuhi persyaratan SNI 19-7030-2004 yaitu $\geq 0,02 \%$ (BSN, 2004).

\section{Rasio C/N}

Perbandingan antara kadar unsur $\mathrm{C}$ dengan kadar unsur $\mathrm{N}$ sebagai parameter kematangan atau kesempurnaan pembentukan kompos. Rasio C/N semakin kecil menunjukan semakin sempurna pembentukan kompos. Rasio $\mathrm{C} / \mathrm{N}$ dibawah 15 merupakan nilai paling ideal untuk pembentukan kompos (kematangan kompos). Hasil perhitungan ratio $\mathrm{C} / \mathrm{N}$ disajikan pada Gambar 4 yang menunjukan bahwa pada perlakuan awal (minggu ke 0) peningkatan jumlah limbah fleshing pada pembuatan kompos menyebabkan rasio $\mathrm{C} / \mathrm{N}$ cenderung naik. Kompos dengan 100 bagian kotoran hewan setelah fermentasi pada minggu ke 0 (pengujian ke-1) menghasilkan kompos dengan rasio $\mathrm{C} / \mathrm{N}$ sebesar 13,63. Hal ini berarti kompos tanpa ditambah limbah fleshing menjadi masak pada fermentasi tanpa bantuan cacing tanah. Dengan budidaya cacing tanah pada inkubasi 2 minggu (pengujian ke-2), menunjukan kenaikan rasio $\mathrm{C} / \mathrm{N}$ sebesar 17,16. Hal ini dimungkinkan karena kadar unsur $\mathrm{N}$ turun sebagai dampak dikomsumsi oleh cacing cacing tanah. 
Sedangkan pada minggu ke-4 (pengujian ke-3) nilai $\mathrm{C} / \mathrm{N}$ rasio menjadi rendah dengan kadar $\mathrm{N}$ yang naik karena adanya degradasi protein dari limbah fleshing.

Kompos dengan perbandingan kotoran hewan dan limbah fleshing berturut-turut 90:10; 80:20; 70:30; 60:40; dan 50:50 maka perpanjangan waktu inkubasi terbukti rasio $\mathrm{C} / \mathrm{N}$ turun. Hal demikian menandakan masih berlangsungnya pemecahan senyawa dalam limbah fleshing seperti protein akan dihasilkan unsusr N. Unsur N dalam kompos naik sampai minggu ke-4 fermentasi dan semua kompos telah masak.

Penurunan tajam kompos dengan campuran limbah fleshing untuk semua perbandingan terjadi pada minggu ke 2 setelah inkubasi cacing tanah. Hal ini dapat diartikan bahwa limbah fleshing terdegradasi optimal sampai minggu ke-2, pada minggu ke-4 penurunan mulai landai dikarenakan senyawa pada limbah fleshing telah banyak didegradasi pada minggu ke-2. Kompos dengan 100 bagian kotoran hewan tanpa penambahan fleshing rasio $\mathrm{C} / \mathrm{N}$ pada minggu ke-4 sangat rendah hal ini diduga karena senyawa-senyawa $\mathrm{C}$ dan $\mathrm{N}$ pada kotoran hewan telah mengalami degradasi pada proses pencernaan hewan sehingga mudah didegradasi menjadi unsur C dan N. Sedangkan pada limbah fleshing senyawa-senyawa masih dalam keadaan berikatan dengan baik sehingga untuk degradasi memerlukan waktu, tetapi kandungan unsur $\mathrm{C}$ dan $\mathrm{N}$ pada limbah fleshing lebih banyak sehingga memungkinkan untuk penggunaan yang lebih lama. Dari percobaan Dickerson (2004), kandungan unsur nitrogen pada kompos dengan kotoran hewan dan tumbuh-tumbuhan tanpa menggunakan cacing tanah sebesar 0,80\%, kompos dengan limbah fleshing dan diproses dengan cacing tanah kandungan unsur $\mathrm{N}$ sebesar $1,94 \%$.

\section{KESIMPULAN}

Limbah Fleshing hasil samping proses penyamakan kulit dapat digunakan untuk campuran pembuatan kompos kotoran sapi dan cacing tanah Esenia Foetida sebagai digester. Perbandingan optimum antara kotoran hewan dan limbah fleshing sebesar 60:40 dengan kompos memiliki rasio $\mathrm{C} / \mathrm{N}$ pada minggu ke-4 fermentasi sebesar 11,22. Nilai keambanan kompos turun seiring turunnya perbandingan kotoran hewan denganfleshing dan perbandingan antara kotoran hewan dan fleshing sebesar 60 :40 maka keambanan media sebesar $1,39 \mathrm{~cm}^{3} / \mathrm{g}$ yang masih memerlukan pembalikan kompos setiap 2 hari.

\section{UCAPAN TERIMA KASIH}

Ucapan terima kasih ditujukan kepada Kepala Balai Besar dan Kepala Bidang SARS Balai Besar Kulit, Karet, dan Plastik, Yogyakarta atas pengarahannya dan juga seluruh Kelompok Kerja 004.003 tahun 2012 atas bantuan dan kerjasamanya sehingga kegiatan penelitian dapat diselesaikan dengan baik dan lancar.

\section{DAFTAR PUSTAKA}

Achmad, K. T. B., Hidayati, J. A., Abdullah, N., and Sutendy, A., 2010. The effect of Lumbricus rubellus seeding density on earthworm biomass and quantity as well as quality of kascing in vermicomposting of cattle feces and bagasse mix, Lucróri Ştiintifice, Seria Zootehnie, 53: 158-163.

BSN (Badan Standardisasi Nasional), 2004. SNI 19-7030-2004 Karakteristik Kompos Sampah Organik.

Deka, H., Deka, S., Baruah, C. K., Das, J., Hoque, S., Sarma, H., and Sarma, N. S., 2011. Vermicomposting potentiality of Perionyx excavatu for recycling of waste biomass of java citronella-An aromatic oil yielding plant, Bioresource Technology, 102(24): 11212-11217.

Dickerson, G. W., 2004. Vermicomposting, Guide H-164, College of Agriculture and Home Economic, New Mexico State University.

Garg, V. K. and Gupta, R., 2011. Optimization of cow dung spiked pre-consumer processing vegetable waste for vermicomposting using Eisenia fetida, Ecotoxicology and Environmental Safety, 74(1): 19-24.

Gómez-Brandón, M., Lores, M., and Domínguez, J., 2013. Changes in chemical and microbiological properties of rabbit manure in a continuous-feeding vermicomposting system, Bioresource Technology, 128: 310316. 
Gurav, M. V. and Pathade G. R., 2011. Production of vermicompost from temple waste (Nirmalya): A case study, Universal Journal of Environmental Research and Technology, 1(2): 182-192.

Kanagaraj, J., Vellapan, K. C., Babu, C. N. K., and Sadulla, S., 2006. Solid Waste generation in the leather industry and it utilization for cleaner environment - A review, Journal of Scientific and Industrial Research, 65(7): 541-548.

Karmakar, S., Brahmachari, K., Gangopadhyay, A., and Choudhury S. R., 2012. Recycling of different available organic waste through vermicomposting, E-Journal of Chemistry, 9: 801-806.

Majlessi, M., Eslami, A., Saleh, H. N., Mirshafieean, S., and Babaii, S., 2012. Vermicomposting of food waste: assessing the stability and maturity, Iranian Journal of Environmental Health Science and Engineering, 9(1): 25-25.

Molina, M. J., Soriano, M. D., Ingelmo, F., and Llinares., J., 2013. Stabilisation of sewage sludge and vinasse bio-wastes by vermicomposting with rabbit manure using Eisenia fetida, Bioresource Technology, 137: 88-97.

Ngo, P. T., Rumpel, C., Dignac, M. F., Billou, D., Duc, T. T., and Jouquet, P., 2011. Transformation of buffalo manure by composting or vermicomposting to rehabilitate degraded tropical soils, Ecological Engineering, 37(2): 269-276.

Pattnaik, S. and Reddy, M. V., 2012. Remediation of heavy metals from urban waste by vermicomposting using earthworms: Eudrilus eugeniae, Eisenia fetida and Perionyx excavatus, International Journal of Environment and Waste Management, 10(2): 284-296.
Paul, J. A., Karmegam, N., and Daniel, T., 2011. Municipal solid waste (MSW) vermicomposting with an epigeic earthworm Perionyx ceylanensis Mich, Bioresource Technology, 102(12): 6769-6773.

Prakash, M. and Karmegam, N., 2010. Dynamics of nutrients and microflora during vermicomposting of mango leaf litter (Mangifera indica) using Perionyx ceylanensis, International Journal of Global Environmental Issues, 10(3): 339353.

Pramanik, P. and Chung, Y. R., 2011. Changes in fungal population of fly ash and vinasse mixture during vermicomposting Eisenia fetida: Documentation of cellulase isozymes in vermicompost, Waste Management, 31(6): 1169-1175.

Raphael, K. and Velmourougane, K., 2011. Chemical and microbiological changes during vermicomposting of coffee pulp using exotic (Eudrilus eugeniae) and native earthworm (Perionyx ceylanesis) species, Biodegradation, 22(3): 497-507.

Singh, D. and Suthar, S., 2012. Vermicomposting of herbal pharmaceutical industry waste: Earthworm growth, plant-available nutrient and microbial quality of end materials. Bioresource Technology, 112: 179-185.

Sinha, R. K., Herat, S., Valani, D., and Chauhan, K., 2009. Vermiculture and sustainable agriculture, American-Eurasian Journal of Agriculture and Environmental Sciences, 5(s): 01-55. 